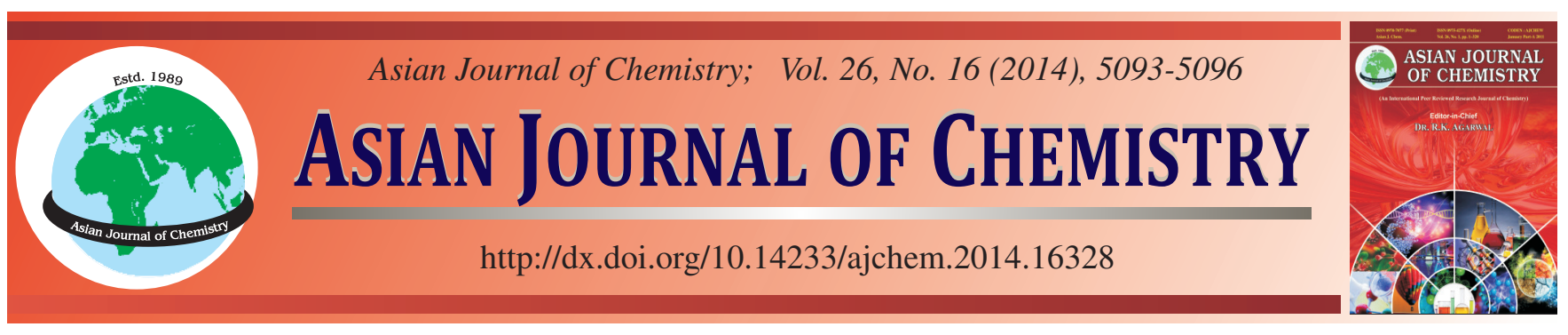

\title{
Synthesis and Structural Characterization of Five-Coordinate Cobalt(II) Complexes Based on tris(2-Benzimidazolymethyl)amine Ligand
}

\author{
Chun-Hua Ge, Li-Hua Li, Ying-Qi Wang, Rui Zhang and Xiang-Dong Zhang*
}

College of Chemistry, Liaoning University, Shenyang 110036, P.R. China

*Corresponding author: Tel: +86 24 62202053; E-mail: xdzhang@lnu.edu.cn

Received: 11 September 2013;

Accepted: 9 December 2013;

Published online: 28 July 2014;

AJC-15637

\begin{abstract}
The synthesis and characterization of three new complexes $2\left[\mathrm{Co}(\mathrm{ntb})\left(\mathrm{H}_{2} \mathrm{mpda}\right)\right] \cdot\left(\mathrm{CH}_{3} \mathrm{COCH}_{3}\right) \cdot 4 \mathrm{H}_{2} \mathrm{O}(\mathbf{1}),\left[\mathrm{Co}(\mathrm{ntb})\left(\mathrm{H}_{2} \mathrm{mpda}\right)\right] \cdot 3 \mathrm{H}_{2} \mathrm{O}(\mathbf{2})$ and $2[\mathrm{Co}(\mathrm{ntb}) \mathrm{Cl}] \cdot\left[\mathrm{Co}(\right.$ edta) $] \cdot 6 \mathrm{H}_{2} \mathrm{O}(3)$ (ntb = N,N,N-tris (2-benzimidazolymethyl)amine, $\mathrm{H}_{4} \mathrm{mpda}=1$,3-phenylenedinitrilotetraacetic acid and $\mathrm{H}_{4}$ edta = ethylenediamine tetraacetic acid) are reported. The molecular structures of these complexes are confirmed by single-crystal X-ray structure analysis. The reaction of $\mathrm{Co}\left(\mathrm{NO}_{3}\right)_{2}$ with ntb and $\mathrm{H}_{4}$ mpda in acetone $/ \mathrm{H}_{2} \mathrm{O} /$ ethanol or $\mathrm{DMF} / \mathrm{H}_{2} \mathrm{O} / \mathrm{methanol}$ gives 1 and 2 , respectively, while the reaction of $\mathrm{CoCl}_{2}$ with ntb and $\mathrm{H}_{4}$ edta in $\mathrm{H}_{2} \mathrm{O}$ /methanol gives 3 . Mononuclear $[\mathrm{Co}(\mathrm{ntb})(\mathrm{L})]$ motif is found in all the compounds, in which $\mathrm{Co}$ (II) is in a five-coordinate environment with a tetradentate $\mathrm{N}_{4}$ coordination ntb ligand and a monodentate second ligand. The diversity of solvent in $\mathbf{1}$ and $\mathbf{2}$ results in slight difference in the coordinate and crystal packing structure. $\mathbf{3}$ is an ionic compound, containing $[\mathrm{Co}(\mathrm{ntb}) \mathrm{Cl}]^{+}$cations and $[\mathrm{Co}(\mathrm{edta})]^{2-}$ anions. The solvent plays significant role in the stabilization of all the threedimensional supramolecular networks through hydrogen bonds.
\end{abstract}

Keywords: Co(II) complex, $N, N, N$-tris(2-benzimidazolymethyl)amine, Five-coordination, Crystal structure.

\section{INTRODUCTION}

Upon coordination of primary ligand to a metal center, there are many factors could influence the coordination structures of metal ion, such as the properties of second ligand and uncoordinated solvent ${ }^{1,2}$. Moreover, compared with coordination polymer, discrete mononuclear complex is more susceptible to the external noncovalent interactions, such as hydrogen bonding, hydrophobic, steric repulsion, aromatic ring stacking and electrostatic interactions $\mathrm{s}^{3-5}$. Of course, it is more difficult to predict and control the crystalline assembly.

$\operatorname{tris}(2$-Benzimidazolymethyl)amine (ntb) is a potential ligand for synthesis of a number of complexes with potential applications, in which the coordinated units have different geometries ${ }^{6-8}$. But, there are few cases about uncoordinated supramolecular extending mode around basic unit. In order to investigate the construction of metal-based supramolecular assemblies, the ntb and second ligand with prominent features of the multiple interaction groups have been employed in this research to generate three $\mathrm{Co}(\mathrm{II})$ complexes: $2\left[\mathrm{Co}(\mathrm{ntb})\left(\mathrm{H}_{2} \mathrm{mpda}\right)\right] \cdot\left(\mathrm{CH}_{3} \mathrm{COCH}_{3}\right) \cdot 4 \mathrm{H}_{2} \mathrm{O}(\mathbf{1}),[\mathrm{Co}(\mathrm{ntb})$ $\left(\mathrm{H}_{2}\right.$ mpda) $] \cdot 3 \mathrm{H}_{2} \mathrm{O}(2)$ and $2\left[\mathrm{Co}(\right.$ ntb) $\mathrm{Cl}] \cdot\left[\mathrm{Co}(\right.$ edta) $] \cdot 6 \mathrm{H}_{2} \mathrm{O}(\mathbf{3})$ (ntb $=N, N, N$-tris(2-benzimidazolymethyl)amine, $\mathrm{H}_{4}$ mpda $=1,3$ phenylenedinitrilotetraacetic acid and $\mathrm{H}_{4}$ edta = ethylenediamine tetraacetic acid). The variation of coordination structures of metal center and three-dimensional networks are mainly achieved by altering solvent and ion.

\section{EXPERIMENTAL}

Reagents and solvents used were purchased from commercial sources and used without further purification. $\mathrm{N}, \mathrm{N}, \mathrm{N}$-tris(2benzimidazolymethyl)amine (ntb) ligand was prepared following the literature ${ }^{9}$. 1,3-Phenylenedinitrilotetraacetic acid $\left(\mathrm{H}_{4} \mathrm{mpda}\right)$ was synthesized by a previously reported method ${ }^{10}$. IR spectra were recorded on a Perkin Elmer Specture one spectrometer in range $4000-400 \mathrm{~cm}^{-1}$ as $\mathrm{KBr}$ pellets. Elemental analyses were determined on an Elementar Vario EL elemental analyzer. TGA (thermal gravimetric analysis) was performed under nitrogen with a heating rate of $10^{\circ} \mathrm{C} / \mathrm{min}$ using a Mettler Toledo TAG/SDTA 851e system.

Synthesis of complex 1: To a solution of ntb $(0.1 \mathrm{mmol})$ in $10 \mathrm{~mL}$ of methanol was added $\mathrm{Co}\left(\mathrm{NO}_{3}\right)_{2} \cdot 6 \mathrm{H}_{2} \mathrm{O}(0.1 \mathrm{mmol})$ in $\mathrm{H}_{2} \mathrm{O}(2 \mathrm{~mL})$ and $\mathrm{H}_{4} \mathrm{mpda}(0.1 \mathrm{mmol})$. This mixture was heated for $2 \mathrm{~h}$. To the reaction solution was added $1 \mathrm{~mL}$ acetone. This mixture was stirred at room temperature for $1 \mathrm{~h}$, then filtrated and allowed to stand at room temperature. After a few days, pink crystals suitable for X-ray crystallography were obtained. IR $\left(\mathrm{KBr}, v_{\max }, \mathrm{cm}^{-1}\right)$ : 3440, 3013, 2929, 1708, 1610, 1576, 1454, 1399, 1316. Yield: $41 \%$. The sample lost solvent molecules quickly while being exposed to air. After solvent 
molecules were removed under vacuum, the elemental analysis based on $\mathrm{Co}(\mathrm{ntb})\left(\mathrm{H}_{2} \mathrm{mpda}\right)$ was performed. Anal. calcd. $\mathrm{C}_{38} \mathrm{H}_{35} \mathrm{~N}_{9} \mathrm{O}_{8} \mathrm{Co}: \mathrm{C}, 56.72 ; \mathrm{H}, 4.38 ; \mathrm{N}, 15.67$. Found: C, 56.22; $\mathrm{H}, 4.97 ; \mathrm{N}, 15.17$.

Synthesis of complex 2: The mixture of $\mathrm{ntb}(0.1 \mathrm{mmol})$ in $10 \mathrm{~mL}$ of methanol, $\mathrm{H}_{4}$ mpda $(0.1 \mathrm{mmol})$ in $5 \mathrm{~mL} \mathrm{DMF}$ and $\mathrm{Co}\left(\mathrm{NO}_{3}\right)_{2} \cdot 6 \mathrm{H}_{2} \mathrm{O}(0.1 \mathrm{mmol})$ in $\mathrm{H}_{2} \mathrm{O}(5 \mathrm{~mL})$ was refluxed for $2 \mathrm{~h}$. The slow evaporation at room temperature of the resulting mixture affords 2 as pink crystals. IR $\left(\mathrm{KBr}, \mathrm{v}_{\max }, \mathrm{cm}^{-1}\right): 3442$, 3029, 2925, 1714, 1654, 1607, 1578, 1453, 1383, 1314. Yield: $32 \%$. The sample lost solvent molecules quickly while being exposed to air. After solvent molecules were removed under vacuum, the elemental analysis based on $\mathrm{Co}(\mathrm{ntb})\left(\mathrm{H}_{2} \mathrm{mpda}\right)$ was performed. Anal. calcd. $\mathrm{C}_{38} \mathrm{H}_{35} \mathrm{~N}_{9} \mathrm{O}_{8} \mathrm{Co}$ : C, 56.72; H, 4.38; N, 15.67. Found: C, 56.89; H, 4.98; N, 15.33.

Synthesis of complex 3: Solutions of ntb $(0.1 \mathrm{mmol})$ in $10 \mathrm{~mL}$ methanol, $\mathrm{H}_{4}$ edta $(0.1 \mathrm{mmol})$ in $10 \mathrm{~mL}$ methanol and $\mathrm{CoCl}_{2} \cdot 6 \mathrm{H}_{2} \mathrm{O}(0.1 \mathrm{mmol})$ in $5 \mathrm{~mL}$ water were combined and refluxed for $1 \mathrm{~h}$. After cooling to room temperature, purple crystals appeared by slow evaporation the mixture. Yield: $68 \%$. IR $\left(\mathrm{KBr}, \mathrm{v}_{\max }, \mathrm{cm}^{-1}\right): 3491,3062,2938,1644,1959,1473$, 1455, 1398, 1280, 1044, 974, 750. The sample lost solvent molecules quickly while being exposed to air. After solvent molecules were removed under vacuum, the elemental analysis based on $2[\mathrm{Co}($ ntb)Cl] $\cdot[\mathrm{Co}($ edta $)]$ was performed. Anal. calcd. $\mathrm{C}_{58} \mathrm{H}_{54} \mathrm{~N}_{16} \mathrm{O}_{8} \mathrm{Cl}_{2} \mathrm{Co}_{3}$ : C, 51.57; $\mathrm{H}, 4.03 ; \mathrm{N}, 16.59$. Found: $\mathrm{C}$, 51.04; H, 4.64; N, 16.97.

X-ray crystallography: Diffraction data for 1, 2 and $\mathbf{3}$ were measured on a Bruker SMART CCD diffractometer at 190(2) K using graphite monochromated, $\mathrm{MoK}_{\alpha}$ radiation $(\lambda=0.71073 \AA)$. The collected data were reduced with the SAINT program ${ }^{11}$ and empirical absorption correction was done with the SADABS ${ }^{12}$ program. Both structures were solved by the direct method and refined by the full-matrix leastsquares method on $\mathrm{F}^{2}$ with anisotropic thermal parameters for all non-hydrogen atoms ${ }^{13}$. The summary of the crystal data, experimental details and refinement results for 1, 2 and $\mathbf{3}$ are listed in Table-1.

\section{RESULTS AND DISCUSSION}

The single-crystal analysis of $\mathbf{1}$ and $\mathbf{2}$ revealed that $\mathbf{1}$ and 2 have almost identical structures as shown in Fig. 1. In both mononuclear complexes, the ligand ntb coordinates with the $\mathrm{Co}(\mathrm{II})$ ion through four $\mathrm{N}$ atoms by a typical tripodal coordination mode. Three benzimidazole $\mathrm{N}$ atoms form the equatorial planes of the trigonal-bipyramid polyhedra. The central Co atom in 1 was displaced $0.489 \AA$ away from the equatorial plane, while the value is $0.521 \AA$ in 2 . The ntb ligand wraps around the central $\mathrm{Co}(\mathrm{II})$ ion showing clockwise ( $\Delta$ enantiomer) propeller coordination fashion in both cases (Fig. 2). The tertiary nitrogen atom of ntb and an oxygen atom of carboxylate group from the $\mathrm{H}_{2} \mathrm{mpda}^{2-}$ ligand occupy the two apical positions. The $\mathrm{H}_{2} \mathrm{mpda}^{2-}$ ligand is not in the space between the benzimidazole groups of ntb, but in the underside of one benzimidazole ring. The dihedral angle between $\mathrm{N}(2)$ containing benzimidazole ring and phenyl ring of $\mathrm{H}_{2} \mathrm{mpda}^{2-}$ is $86.18^{\circ}$ in $\mathbf{1}$, that value is $89.33^{\circ}$ in 2 . Carboxylic acid and carboxylate groups of $\mathrm{H}_{2} \mathrm{mpda}^{2-}$ ligand form intramolecular

\begin{tabular}{|c|c|c|c|}
\hline \multicolumn{4}{|c|}{$\begin{array}{c}\text { TABLE-1 } \\
\text { CRYSTALLOGRAPHIC DATA FOR COMPLEXES 1-3 }\end{array}$} \\
\hline Complex & 1 & 2 & 3 \\
\hline Formula & $\begin{array}{c}2\left(\mathrm{C}_{38} \mathrm{H}_{35} \mathrm{CoN}_{9} \mathrm{O}_{8}\right) \\
\mathrm{C}_{3} \mathrm{H}_{6} \mathrm{O} \cdot 4\left(\mathrm{H}_{2} \mathrm{O}\right)\end{array}$ & $\begin{array}{c}\mathrm{C}_{38} \mathrm{H}_{35} \mathrm{Co} \\
\mathrm{N}_{9} \mathrm{O}_{8} \cdot 3\left(\mathrm{H}_{2} \mathrm{O}\right)\end{array}$ & $\begin{array}{c}2\left(\mathrm{C}_{24} \mathrm{H}_{21} \mathrm{ClCoN}_{7}\right) \\
\mathrm{C}_{10} \mathrm{H}_{12} \mathrm{CoN}_{2} \mathrm{O}_{8} . \\
6\left(\mathrm{H}_{2} \mathrm{O}\right)\end{array}$ \\
\hline $\begin{array}{c}\text { Formula } \\
\text { weight }\end{array}$ & 1739.50 & 858.73 & 1458.96 \\
\hline Crystal system & Triclinic & Triclinic & Monoclinic \\
\hline $\mathrm{a}, \AA$ & $12.495(2)$ & $12.509(2)$ & $16.158(1)$ \\
\hline $\mathrm{b}, \AA$ & $12.860(2)$ & $12.728(2)$ & 24.533(2) \\
\hline $\mathrm{c}, \AA$ & 14.715(3) & $14.731(2)$ & $16.652(1)$ \\
\hline$\alpha, \operatorname{deg}$ & $76.750(3)$ & $77.307(2)$ & 90.00 \\
\hline$\beta, \operatorname{deg}$ & $65.994(3)$ & $66.054(2)$ & $101.350(1)$ \\
\hline$\gamma, \operatorname{deg}$ & $77.532(3)$ & $77.312(2)$ & 90.00 \\
\hline $\mathrm{V} / \AA^{3}$ & $2082.3(6)$ & $2068.6(3)$ & $6471.7(7)$ \\
\hline Temperature/K & $190(2)$ & $190(2)$ & $190(2)$ \\
\hline Space group & P1 & P1 & $\mathrm{C} 2 / \mathrm{c}$ \\
\hline $\mathrm{Z}$ & 1 & 2 & 4 \\
\hline$\mu / \mathrm{mm}^{-1}$ & 0.481 & 0.484 & 0.919 \\
\hline $\mathrm{R}_{\mathrm{int}}$ & 0.0430 & 0.0238 & 0.0233 \\
\hline $\begin{array}{l}\text { R indices } \\
(I>2 \sigma(I))\end{array}$ & $\begin{array}{l}\mathrm{R}_{1}=0.0814 \\
\mathrm{wR}_{2}=0.1874\end{array}$ & $\begin{array}{l}\mathrm{R}_{1}=0.0624 \\
\mathrm{wR}_{2}=0.1919\end{array}$ & $\begin{array}{l}\mathrm{R}_{1}=0.0607 \\
\mathrm{wR}_{2}=0.1776\end{array}$ \\
\hline $\begin{array}{l}\text { Final } \mathrm{R} \text { indices } \\
\text { (all data) }\end{array}$ & $\begin{array}{l}\mathrm{R}_{1}=0.1552 \\
\mathrm{wR}_{2}=0.2292\end{array}$ & $\begin{array}{l}\mathrm{R}_{1}=0.0918 \\
\mathrm{wR}_{2}=0.2170\end{array}$ & $\begin{array}{l}\mathrm{R}_{1}=0.0711 \\
\mathrm{wR}_{2}=0.1869\end{array}$ \\
\hline $\begin{array}{l}\text { Goodness of } \\
\text { fit on } F^{2}\end{array}$ & 1.032 & 1.072 & 1.052 \\
\hline
\end{tabular}

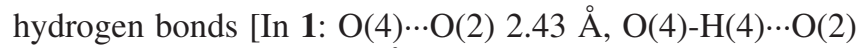
$156.12^{\circ}$; O $7 \cdots \mathrm{O} 52.53 \AA$, O $7-\mathrm{H} 7 \cdots \mathrm{O} 51^{161.95^{\circ}}$. In 2: $\mathrm{O}(4) \cdots \mathrm{O}(2) 2.44 \AA, \mathrm{O}(4)-\mathrm{H}(4) \cdots \mathrm{O}(2) 158.07^{\circ}$; O $7 \cdots \mathrm{O} 52.533$ $\AA$, O7-H7...O5 $16.75^{\circ}$ ]. The subtle difference of the coordination environment between $\mathbf{1}$ and $\mathbf{2}$ is listed in Table-2. All water molecules of $\mathbf{1}$ and $\mathbf{2}$ are linking coordination units to form a three dimensional hydrogen bonded network. The acetone molecule is trapped in the supramolecular cavity by $\mathrm{C}-\mathrm{H} \cdots \pi$ interaction, that is, acetone molecule does not have a significant effect on the coordination sphere.

\begin{tabular}{|c|c|c|c|}
\hline \multicolumn{4}{|c|}{$\begin{array}{c}\text { TABLE-2 } \\
\text { SELECTED BOND LENGTHS (§) AND BOND ANGLES (DEG) }\end{array}$} \\
\hline \multicolumn{4}{|c|}{1} \\
\hline $\mathrm{Co}(1)-\mathrm{N}(1)$ & $2.349(5)$ & $\mathrm{N}(1)-\mathrm{Co}(1)-\mathrm{N}(6)$ & $76.7(2)$ \\
\hline $\mathrm{Co}(1)-\mathrm{N}(6)$ & $2.033(6)$ & $\mathrm{Co}(1)-\mathrm{N}(4)$ & $2.044(5)$ \\
\hline $\mathrm{Co}(1)-\mathrm{O}(1)$ & $2.037(5)$ & $\mathrm{N}(1)-\mathrm{Co}(1)-\mathrm{N}(4)$ & $75.5(2)$ \\
\hline $\mathrm{Co}(1)-\mathrm{N}(2)$ & $2.043(6)$ & $\mathrm{N}(1)-\mathrm{Co}(1)-\mathrm{O}(1)$ & $169.9(2)$ \\
\hline $\mathrm{N}(1)-\mathrm{Co}(1)-\mathrm{N}(2)$ & $76.2(2)$ & $\mathrm{Co}(1)-\mathrm{N}(6)$ & $2.033(6)$ \\
\hline \\
\hline $\mathrm{Co}(1)-\mathrm{N}(1)$ & $2.442(4)$ & $\mathrm{N}(1)-\mathrm{Co}(1)-\mathrm{N}(6)$ & $75.54(15)$ \\
\hline $\mathrm{Co}(1)-\mathrm{O}(1)$ & $2.021(4)$ & $\mathrm{Co}(1)-\mathrm{N}(4)$ & $2.036(4)$ \\
\hline $\mathrm{N}(6)-\mathrm{Co}(1)-\mathrm{O}(1)$ & $96.52(16)$ & $\mathrm{N}(1)-\mathrm{Co}(1)-\mathrm{N}(4)$ & $74.70(15)$ \\
\hline $\mathrm{Co}(1)-\mathrm{N}(2)$ & $2.046(4)$ & $\mathrm{N}(1)-\mathrm{Co}(1)-\mathrm{O}(1)$ & $167.15(16)$ \\
\hline $\mathrm{N}(1)-\mathrm{Co}(1)-\mathrm{N}(2)$ & $75.47(16)$ & $\mathrm{Co}(1)-\mathrm{N}(6)$ & $2.038(4)$ \\
\hline \multicolumn{4}{|l|}{ 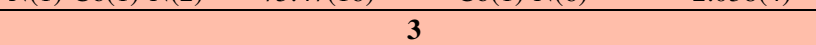 } \\
\hline $\operatorname{Co}(1)-\mathrm{N}(1)$ & $2.360(3)$ & $\mathrm{N}(1)-\mathrm{C}$ & $74.85(13)$ \\
\hline $\mathrm{Co}(1)-\mathrm{Cl}(1)$ & $2.345(2)$ & $\mathrm{Co}(1)-\mathrm{N}(4)$ & $2.039(4)$ \\
\hline $\mathrm{N}(6)-\mathrm{Co}(1)-\mathrm{Cl}(1)$ & $101.11(10)$ & $\mathrm{N}(1)-\mathrm{Co}(1)-\mathrm{N}(4)$ & $75.07(14)$ \\
\hline $\mathrm{Co}(1)-\mathrm{N}(2)$ & $2.054(4)$ & $\begin{array}{l}\mathrm{N}(1)-\mathrm{Co}(1)- \\
\mathrm{Cl}(1)\end{array}$ & $174.85(10)$ \\
\hline $\mathrm{N}(1)-\mathrm{Co}(1)-\mathrm{N}(2)$ & $76.85(13)$ & $\mathrm{Co}(1)-\mathrm{N}(6)$ & $2.057(3)$ \\
\hline
\end{tabular}

Complex 3 consists of cationic and anionic coordination units with a molar ratio of 1:2. The coordination geometry of $[\mathrm{Co}(\mathrm{ntb}) \mathrm{Cl}]^{+}$unit is best described as being based on a trigonal bipyramidal arrangement in which the axial positions are 

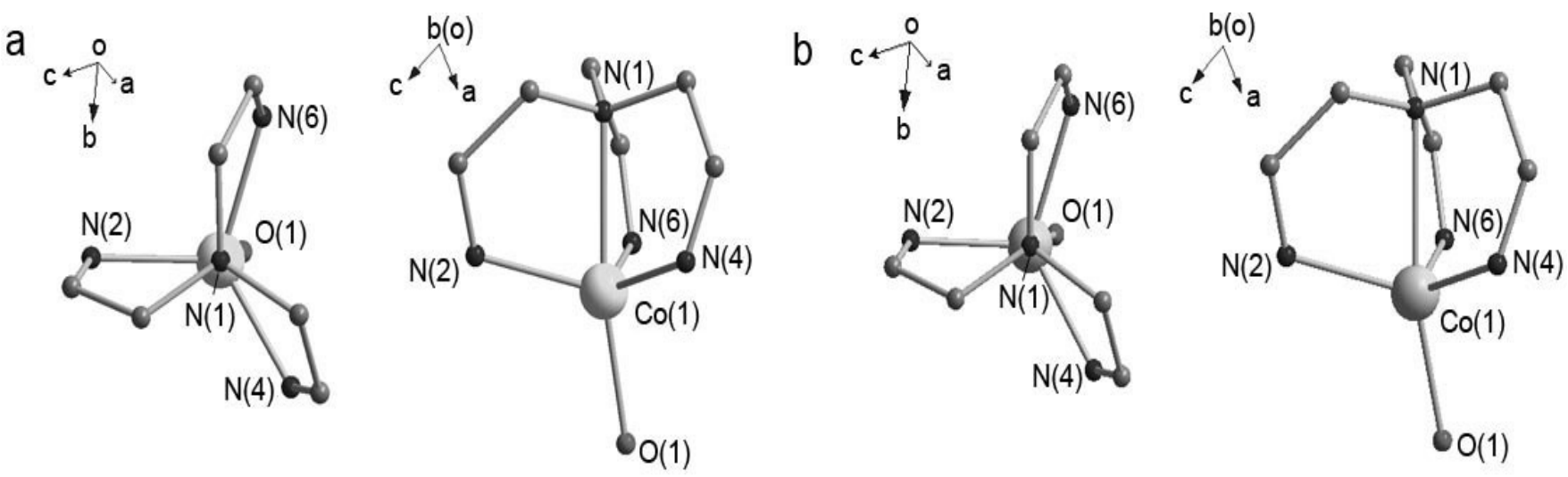

Fig. 2. View of coordination environment from different directions in $\mathbf{1}(\mathrm{a})$ and $\mathbf{2}$ (b)

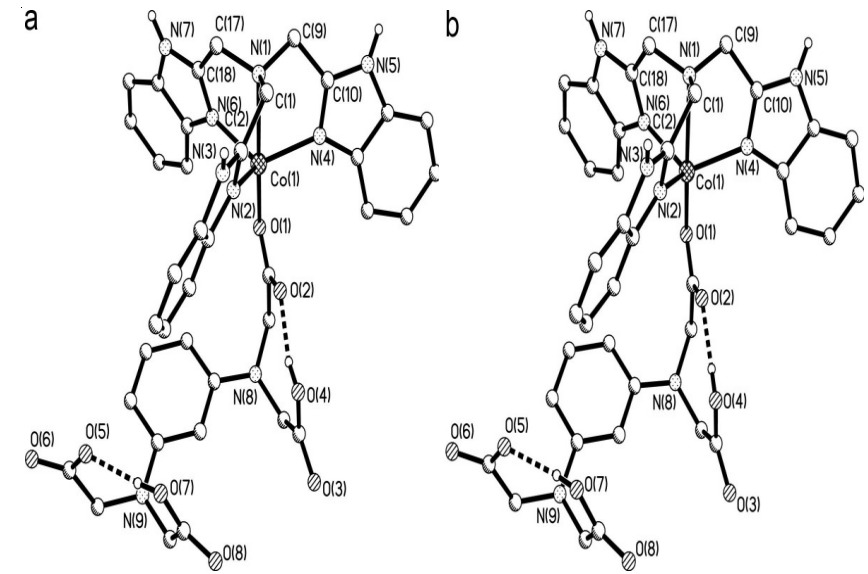

Fig. 1. Plots of complex 1(a) and 2(b). The uncoordinated solvent molecules and hydrogen atoms except these attaching nitrogen and oxygen atoms have been omitted for clarity

defined by the $\mathrm{N}(1)$ and $\mathrm{Cl}(1)$ atoms (Fig. 3a). Cobalt atom lies $0.511 \AA$ out of the plane in the direction of the $\mathrm{Cl}(1)$ atom. The $\mathrm{Co}-\mathrm{Cl}$ distance of 2.345(2) $\AA$ is comparable to reported distances in $[\mathrm{Co}(\mathrm{II})(\mathrm{ntb}) \mathrm{Cl}] \mathrm{Cl}$ complex ${ }^{14}$. Three atoms in the axial direction are closer to the linear arrangement [N(1)$\left.\mathrm{Co}(1)-\mathrm{Cl}(1) 174.85(10)^{\circ}\right]$ than that in $1[\mathrm{~N}(1)-\mathrm{Co}(1)-\mathrm{O}(1)$ $\left.169.9(2)^{\circ}\right]$ and $2\left[\mathrm{~N}(1)-\mathrm{Co}(1)-\mathrm{O}(1) 167.15(16)^{\circ}\right]$, which is mainly attribute to the steric repulsion of chlorine is smaller than $\mathrm{H}_{2} \mathrm{mpda}^{2-}$ ligand (Fig. 3b). In counter $[\mathrm{Co}(\mathrm{edta})]^{2-}$ unit, each $\mathrm{Co}$ (II) atom is surrounded by two nitrogen donors as well as four oxygen atoms from same edta ${ }^{4-}$ organic anion, which exhibits a distorted octahedral coordination sphere. The Co-O bond lengths range between 2.044(3) and 2.131(3) $\AA$, while the Co-N bond length is 2.137(4) $\AA$, which is in the normal range. Each anionic coordination unit is directly connected to two cationic coordination units by hydrogen bonds between carboxylic group and benzimidazole $[\mathrm{N}(3) \cdots \mathrm{O}(2)$ (symmetry code: $1 / 2-x, 1 / 2-y,-z) 2.70 \AA, N(3)-H(3) \cdots O(2) 151.27^{\circ}$ ]. They are also indirectly connected through the bridging water molecules to form complicated three dimensional supramolecular networks.

\section{Conclusion}

In summary, three five-coordinate cobalt(II) complexes $2\left[\mathrm{Co}(\mathrm{ntb})\left(\mathrm{H}_{2} \mathrm{mpda}\right)\right] \cdot\left(\mathrm{CH}_{3} \mathrm{COCH}_{3}\right) \cdot 4 \mathrm{H}_{2} \mathrm{O}(\mathbf{1}),[\mathrm{Co}(\mathrm{ntb})$ $\left.\left(\mathrm{H}_{2} \mathrm{mpda}\right)\right] \cdot 3 \mathrm{H}_{2} \mathrm{O}(2)$ and $2[\mathrm{Co}(\mathrm{ntb}) \mathrm{Cl}] \cdot[\mathrm{Co}($ edta $)] \cdot 6 \mathrm{H}_{2} \mathrm{O}(3)$ have been synthesized and characterized. They exhibit mixed-ligand three-dimensional hydrogen bonding supramolecular networks. The coordination of negative divalent ligand $\mathrm{H}_{2} \mathrm{mpda}^{2-}$ to the cobalt(II) ions leads to neutral complexes $\mathbf{1}$ and $\mathbf{2}$. In complex $\mathbf{3}$, cationic coordination unit is reached by auxiliary ligand $\mathrm{Cl}^{-}$, anionic $\mathrm{Co}(\text { edta })^{2-}$ counterbalancing the charge in this case. Complex $\mathbf{1}$ and $\mathbf{2}$ show that the variation of uncoordinated solvent molecules don't lead to obvious different coordination modes. The structure of complex $\mathbf{3}$ indicates that the smaller second ligand is able to reduce the space steric hindrance effect. a

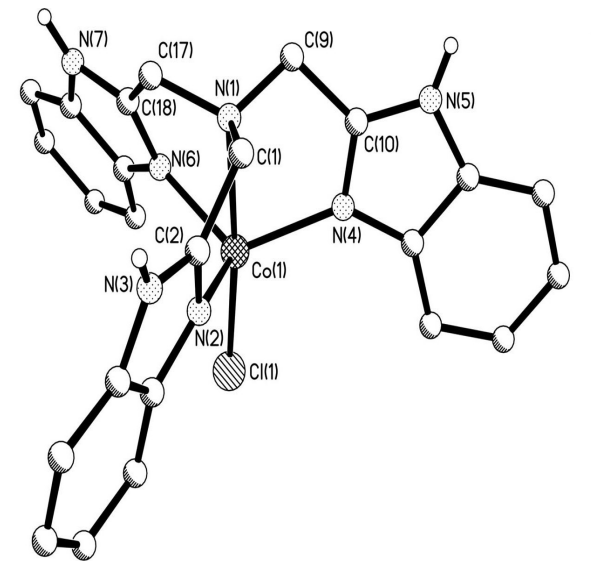

b
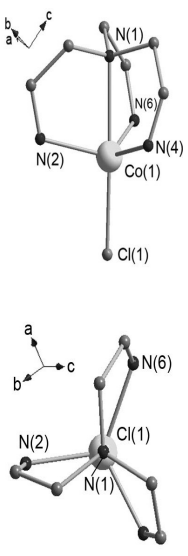

Fig. 3. Crystal structure of the cationic coordination unit (a) and coordination environment (b) in complex $\mathbf{3}$

\section{ACKNOWLEDGEMENTS}

The authors acknowledged the financial support provided by the National Natural Science Foundation of China (No. 20971062/B010303 and No. 21171081/B0103), Natural Science Foundation of Liaoning Province (No. 201202093 and 2013020085), Liaoning Provincial Department of Education Innovation Team Projects (No. LT2012001) and Foundation of 211 Project for Innovative Talents Training (Liaoning University).

\section{REFERENCES}

1. J. He, J.X. Zhang, G.P. Tan, Y.G. Yin, D. Zhang and M.H. Hu, Cryst. Growth Des., 7, 1508 (2007).

2. M. Mehring, G. Gabriele, S. Hadjikakou, M. Schürmann, D. Dakternieks and K. Jurkschat, Chem. Commun., 834 (2002).

3. A.D. Garnovskii, I.S. Vasilchenko, D.A. Garnovskii and B.I. Kharisov, J. Coord. Chem., 62, 151 (2009).

4. K. Ghosh, N. Tyagi, P. Kumar, U.P. Singh and N. Goel, J. Inorg. Biochem., 104, 9 (2010). 
5. M.F. Brown, B.R. Cook and T.E. Sloan, Inorg. Chem., 17, 1563 (1978).

6. X. Meng, L. Liu, H. Zhang, Y. Luo and C. Liu, Dalton Trans., 40, 12846 (2011).

7. J.J. Jiang, S.R. Zheng, Y. Liu, M. Pan, W. Wang and C.Y. Su, Inorg. Chem., 47, 10692 (2008).

8. J.J. Jiang, L. Li, M.H. Lan, M. Pan, A. Eichhöfer, D. Fenske and C.Y. Su, Chem. Eur. J., 16, 1841 (2010).

9. A.R. Oki, P.K. Bommarreddy, H.M. Zhang and N. Hosmane, Inorg. Chim. Acta, 231, 109 (1995).

10. X.D. Zhang, C.H. Ge, F. Yu, Q.T. Liu and M.L. Zhu, Acta Crystallogr. C, 63, m519 (2007).
11. SAINT, Software for SMART Detector, Bruker Axs Inc. Madison, Wisconsin, USA.

12. G.M. Sheldrick, SADABS Program for Empirical Absorption Correction of Area Detector Data, University of Gottingen, Germany (1996).

13. (a) G.M. Sheldrick, SHELXS-97, Structure Solving Program, University of Göttingen, Germany (1997); (b) G.M. Sheldrick, SHELXL-97, Program for the Refinement of Crystal Structures from Diffraction Data, University of Göttingen, Germany (1997); (c) G.M. Sheldrick, Acta Crystallogr. A, 64, 112 (2008).

14. M.S. Lah and M. Moon, Bull. Korean Chem. Soc., 18, 406 (1997). 